\title{
The Effectiveness of Multiple Intelligences (MI)-Based English Classroom Activities at The Eleventh Grade Students of SMAN 2 Mamuju of West Sulawesi
}

\author{
Asriani Ridwan \\ lianiazzahra@gmail.com \\ Graduate Program \\ State University of Makassar, Indonesia
}

\begin{abstract}
The objectives of this research were to find out: (1) the students' MI profiles, (2) whether the implementation of MI-Based English Classroom Activities could increase the students' English achievement or not, and (3) whether the students are interested toward the implementation of MI-Based English Classroom Activities or not. This research was conducted through Quasi-Experimental Method. The population of the research was the eleventh grade students of the second semester in SMAN 2 Mamuju of West Sulawesi Province in 2014/2015. This sample was selected through purposive random sampling technique. The data of the research were analyzed inferential and descriptive statistic. The results of the research were: (1) the students' MI profiles showed $80.6 \%$ students in existential and interpersonal intelligences, $74.2 \%$ students in verbal-linguistic and naturalist intelligences, $67.7 \%$ students in logical-mathematical and musical intelligences, $58.1 \%$ students in visual-spatial intelligence, $51.6 \%$ students in bodily-kinesthetic and intrapersonal intelligences, (2) the implementation of MI-Based English Classroom Activities could increase students' English achievement (3) The students were interested toward the implementation of MI-Based English Classroom Activities. So it can be concluded that the implementation of MI-Based English Classroom Activities was very effective to be applied in increasing the students' English Achievement.
\end{abstract}

Key words: Multiple Intelligence (MI) and English Classroom Activities.

\section{INTRODUCTION}

Teaching English in the classroom requires some sets of role to support the success of teaching and learning process. The sets of role include curriculum and material development, using effective and creative strategy in teaching and learning process in the classroom. To acquire process and optimal teaching and learning objectives, the teacher must implement appropriate strategies. Chatib (2011:129) states teaching and learning strategy is an operational plan of attainment something that facilitates students in understanding the components of learning process. Effective strategy of 
teaching English will ensure students' success in learning process. Furthermore, effective strategy in teaching English will have a positive impact on raising students' attainment and achievement.

As a social reality in education field, there are still many teachers that cannot distinguish the main objective of teaching, learning, instruction and curriculum. In addition to the reality, there are also many teachers that do not know how to choose the appropriate strategy in teaching and learning process. Chatib (2011a, 2011b:127) states that teaching and learning is a process that involve teacher, student and others learning tools to achieve the goal of education namely to make humanize the learners/students. The success of teaching and learning process depends on the implementation of appropriate strategy that employed by teacher.

There are many teachers that do not know and understand what basic needs are required by students and what student's intelligences are owned by students. Sometimes the teacher considers that an intelligent student is a capable student in mathematic subject and the teacher refuses the various intelligences that owned by the student. Gardner (1983) argues against the uniform view of intelligence by suggesting a pluralistic view of human mind. He believes that human beings have eight distinct intellectual potentials which operate together in coping with the world. The view about diversity potential of each individual or learner is referred on Gardner's theory which often called Theory of Multiple Intelligences. This theory had been introduced by Gardner (1983) who puts forward an argument regarding two approaches to intelligence: (i) the uniform view and (ii) pluralistic view of mind. Favouring the pluralistic view of mind, he suggests an individualcentred school with a multifaceted view of intelligence. He expects to contribute to the realization of individuals' needs in improving and achieving the ultimate intellectual potential.

Because of the several of intelligences that owned by student, Multiple Intelligences can be applied as an appropriate strategy in the English classroom. Christison (1996) suggests that teachers can teach students about the MI theory to help them be aware of their own intelligences and use them while learning. Moreover, Christison (1996) mentions four stages which can be used in lessons based on the MI theory: (i) stimulate and encourage the intelligence, (ii) develop and emphasize them, (iii) design lessons based on the multiple intelligences, and include them and (iv) to solve problems.

The MI makes it possible for teachers to give individualized instruction by identifying students' strong and weak intelligences, and individualizing the learning process to help the students to activate the intelligences which are less developed (Chapman, 1993). Gardner's theory offered a wide variety of practical applications to teachers and educators in order to improve language 
classroom practices and match intellectual profiles with educational opportunities.

Based upon the rational explanation above, the researcher would like to formulate research questions: 1. what are the students' MI profiles? 2. Can the implementation of MI-Based English Classroom Activities increase students' achievement? 3. Are the students interested toward the implementation of MI-Based English Classroom Activities? The objectives of this research were formulated to find out: 1. the students' MI profiles, 2 . whether the implementation of MI-Based English Classroom Activitiescould increase the students' achievement or not, 3. whether the students interested toward the implementation of Multiple Intelligence (MI)-Based English Classroom Activities or not.

\section{LITERATURE REVIEW}

\section{Related Studies}

Ibnian S. S. K (2013)had investigated about "Implications of Multiple Intelligences theory in ELT Field". He stated thatin the second language classroom is possible to motivate learners by activating multiple ways of meaning-making through the use of tasks relating to the different intelligences or Multiple Intelligences.

Soleimani, et al (2012) had explored his research under the title "The Effect of Instruction Based on Multiple Intelligences Theory on the Attitude and Learning of General English". The purpose of the study is investigation and comparison of the effect of teaching general English coursebased on Multiple Intelligences and traditional way of teaching on achievement in learning English and attitudestowards English course.Analysis of thestatistical results indicates that there is statistical difference between mean scores of the experimental and controlgroups in pre-test and posttest.Consequently it can be said that generally there is a meaningful difference between Multiple Intelligences based teaching and traditionalbased teaching in achievement of English course instudents. In other words, instruction based on Multiple Intelligences in comparison with traditional way ofteaching has been more effective.

Hajhashemi (2011)conducted his research under the title "The Relationship between Iranian EFL High School Students' Multiple Intelligences Scores and their Use of Learning Strategies". He hadinvestigated the relationship between Multiple Intelligences (MI) profiles and Language Learning Strategies (LLS) used by Iranian EFL highschool students. The findings 
revealed that there is a low, positive correlation between the two variables, $r$ $=0.24$. Alow, positive correlation between MI and different strategy types was another finding of the present study. Also, thehighest correlation was found between meta-cognitive strategies and MI, followed by compensation and cognitivestrategies. As for the frequency of use of learning strategies, the study shed light on the fact that Iranian studentshave a stronger tendency to use meta-cognitive strategies, followed by social strategies. Becauseof MI and learning strategies, both teachers and learners can improve their EFL classes. Having access to MI profiles and learning strategies of learners will help theteachers in planning activities to connect both strategies and students' talents and provide students with the bestpossible instruction.

Ibragimova (2011) carried out his study about "Multiple Intelligences Theory in Action in EFL Classes: A Case Study".The results of his study may have some practical and theoretical implications. First of all, it may help language teachers in designing or adapting materials in terms of Multiple Intelligences Theory to better cater for the students' Multiple Intelligences and, as a whole, improve learning and teaching process. Moreover, the framework can be used in various educational and cultural contexts to analyze textbooks of different levels. Finally, the findings of this study may contribute to the related literature regarding of the application of Multiple Intelligences in language classes.

Furthermore, Chauhan (2009:4) conducted his research about "Effectiveness of Multiple Intelligences Based Teaching in Teaching English for Primary School Students". He concluded that Multiple Intelligences Based Teaching is an effective method in teaching and learning English among primary school students. The collected data were subjected to the following statistical analysis to arrive the meaningful conclusion. It is inferred that in the control group, $20 \%$ students have low level, $70 \%$ of them have moderate level and $10 \%$ of them have high level of gain scores. In the experimental group, $10 \%$ of students have low level, $63.33 \%$ of them have moderate level and 26.67 $\%$ of then have high level of gain scores. Results showed that the students in the experimental group receiving MI-based instruction performed better than those in the control group. It proved that the research was successful to use effectiveness of Multiple Intelligences Based Teaching in Teaching English for Primary School Students.

\section{Theoretical Background}

The concept of Multiple Intelligences had developed by Howard Gardner, a professor of Psychology in Harvard University. Gardner (1983:34) put forward the theory of Multiple Intelligences (MI), a new view of human intelligence as a result of his dissatisfaction with the traditional IQ tests. 
Gardner (1999:31) worked with gifted and ordinary children at Harvard's Project Zero trying to "understand the development of human cognitive capacities" and he came up with a definition of intelligence as "a biological potential to process information that can be activated in a cultural setting to solve problems or create products that are valued in a culture".

According to Gardner's theory of MI, individuals possess at least eight intelligences which are independent and can be genetically inherited, developed or improved through education or social environment. As Gardner did not support the results of psychometric measures of human intelligence, he started searching for appropriate scientific data to validate the existence of Multiple IntelligencesGardner defines intelligence as 'the capacity to solve problems or to fashion products that are valued in one or more cultural setting' (Gardner \& Hatch, 1989). The explanation of each type of intelligenceis presented below:

1. Logical-Mathematical Intelligence:consists of the ability to detect patterns, reason deductively and think logically. This intelligence is most often associated with scientific and mathematical thinking. This intelligence includes both mathematical and scientific abilities. Mathematicians, scientists and logicians naturally have well-developed skills of working with abstraction and a desire for exploration (Chapman, 1993; Gardner, 1993; Gardner, 1999).

2. Linguistic Intelligence:involves having a mastery of language. This intelligence includes the ability to effectively manipulate language to express oneself rhetorically or poetically. It also allows one to use language as a means to remember information. This intelligence consists of the ability to manipulate words and to use language to express and understand complex meanings. Authors, poets, journalists, speakers, and newscasters demonstrate high levels of linguistic intelligence (Campbell, et al, 1996; Gardner, 1993).

3. Visual-spatial Intelligence:gives one the ability to manipulate and create mental images in order to solve problems. This intelligence is not limited to visual domains-- Gardner notes that spatial intelligence is also formed in blind children. This intelligence entails the distinctive ability to understand the visual world perfectly. Those showing high level of spatial intelligence are able to correspond to spatial information graphically and have well developed mental images (Chapman, 1993).

4. Musical Intelligence:encompasses the capability to recognize and compose musical pitches, tones, melody, rhythms and tone musical composition and performance (Gardner 1999). Those representing this intelligence include composers, conductors, musicians, critics, instrument 
makers, as well as sensitive listeners (Campbell, et al, 1996).Typical skills indicating musical intelligence can be recognizing simple songs and being able to vary speed, tempo, and rhythm in simple melodies (Christison, 1996).

5. Bodily-Kinesthetic Intelligence:is the ability to use one's mental abilities to coordinate one's own bodily movements. This intelligence challenges the popular belief that mental and physical activities are unrelated. This intelligence involves the ability to solve problems and fashion products by using one's bodily movements (Gardner, 1993). Typically, athletes, dancers, surgeons, craftspeople demonstrate highlydeveloped bodily-kinesthetic ability (Campbell, et al, 1996).

6. Interpersonal intelligence:the ability to understand and discern the feelings and intentions of others. This intelligence is the ability to value and cooperate effectively with others. It is highly marked in successful teachers, social workers, actors, salespeople, clinicians, religious leaders or politicians (Campbell, et al, 1996; Gardner, 1993). For example, skills such as responding effectively to other people, problem solving, and resolving conflict are typical for interpersonal intelligence (Christison, 1996).

7. Intrapersonal intelligence:the ability to understand one's own feelings and motivations. These two intelligences are separate from each other. Nevertheless, because of their close association in most cultures, they are often linked together. This intelligence refers to the ability to construct an accurate representation of oneself and to use it effectively in directing one's life (Campbell, et al, 1996; Gardner, 1993).

8. Naturalist Intelligence:Designates the human ability to discriminate among living things (plants, animals) as well as sensitivity to other features of the natural world (clouds, rock configurations). This ability was clearly of value in our evolutionary past as hunters, gatherers, and farmers; it continues to be central in such roles as botanist or chef. It is also speculated that much of our consumer society exploits the naturalist intelligences, which can be mobilized in the discrimination among cars, sneakers, kinds of makeup, and the like. (Brualdi, 1996).

9. Existential Intelligence: the ability of macro-viewing and understanding in a large context. This type of intelligence seeks connecting to real world understandings and applications of new learning. This intelligence is sensitivity and capacity to tackle deep questions about human existence, such as the meaning of life, why do we die, and how did we get here. 
A thorough review of different sources (Berman, 1998; Campbell, et al, 1996; Christison, 1996) regarding the practical applications of MI Theory in language classrooms, revealed a variety of activities addressing eighth intelligence types. These activities are categorized under eight intelligence types and presented below:

\section{Activities catering for logical-mathematical intelligence:}

Crossword, ordering, matching, categorizing and classifying, science demonstration and experiments, logic puzzles and games, story problems with numbers, logical/sequential presentation of subject matter, summarizing, analyzing grammar, solving word problems, creating categories for spelling/vocabulary, organizing information with Venn diagrams, determining cause and effect, sequencing events in a story, designing and conducting an experiment, making up syllogisms to demonstrate, making up analogies to explain, describing the patterns or symmetry, number games, critical thinking, science combinations, mental calculations, guided discovery, syllogisms, comparing, phrasal verb grids, sequencing/ordering, predicting, identifying errors, inferring, giving reasons and defending them, testing hypothesis, examining pairs to choose the correct answer (grammar/vocabulary exercises), identifying main ideas/components/attributes, describing patterns of the causally related event sequences in stories.

2. Activities catering for linguistic intelligences: Note-taking, listening to lectures/stories, reading books/response journals, reading with a partner, sustained silent reading, storytelling, debates, tape recording, teacher reading to students, translating, presenting materials orally, writing a poem, myth, legend, short play, news article, creating a talk show radio program, conducting an interview, composition, literature, word games, poetry, writing, speaking, using language in games, puzzles and creative activities, group discussions, completing worksheets, giving presentations, word building games, memorizing, exercising four skills, completing worksheets, yes/no questions, asking questions, identifying various themes, round table discussion, answering comprehension questions.

3. Activities catering for spatial intelligence: Using charts and grids, clusters, videos, slide, movies, using art, graphic organizers, illustrating stories, using sentence strips, using drawings to express ideas and feelings, making maps, charts, sequencing sentences to form a coherent story, creating a slideshow, videotape or photo album, inventing a board or card game to demonstrate, illustrate, sketch and sculpt, art activities, imagination games, geometric figures, visualization, problem solving, communicating visually, enjoying creative puzzles, maps, designs, 3-D 
models and graphic representations, mind maps, visualizations, diagrams, $\mathrm{TV}$, interpreting visual information, photographs, art work, drawing, creating visual summary, painting, flow charts, card games, visual outlines.

4. Activities catering for bodily-kinesthetic intelligence: Hands-on activities, field trips, role-plays, pantomime, Total Physical Response, field experiences, creating a movement or a sequence of movements to explain, making task or puzzle cards, building or constructing, art forms, movements, drama, sports, manipulative, object coordination, dancing, crafts, miming, circle dancing, brain gym, relaxation exercises, craftwork, using computers, acting, classroom games, mingling in the classroom, simulations, find someone who... game, circulating round the classroom, tracing intonation contours with arms and fingers while saying a given utterance, outcome balls and cards.

5. Activities catering for intrapersonal intelligence: Tasks with selfevaluation component, interest centers, options for homework, personal journal keeping, dialogue journals, learning logs, choice in assignments, describing qualities you possess, setting and pursuing a goal to, describing one of your personal values about, writing a journal entry on, assessing your own work, individualized instruction, independent study, reflective practices and activities, teaching for achievement and success, introspective and meta cognitive tasks, project work, learner diaries, selfstudy, personal goal setting, discussion about what is important and of value in life, reflecting on the personal importance of what is being learned, reacting to the qualities, values, and actions of those featured in stories or poems, expressing feelings and emotions, evaluating web sites.

6. Activities addressing to interpersonal intelligence: Pair work or peer teaching, board games, group brainstorming, group problem solving, project work, pen pals, writing group stories, playing vocabulary games, peer editing, intercultural awareness, conducting a meeting, using social skills to learn about, participating in a service project, teaching someone about, practice giving and receiving feedback on, using technology to, tutoring, cooperative learning, role playing, collective writing, information-gap activities, conducting a class survey, teamwork games/exercises, peer feedback.

7. Activities catering for musical intelligence: Singing, playing recorded music, playing live music (piano, guitar), jazz chants, reciting poetry, associating music to story mood/story plot, writing song lyrics, using rhythm to learn/present intonation patterns, giving presentation with appropriate musical accompaniment, explaining, sound 


\section{4| ELT Worldwide Vol. 2 No. 2 October 2015}

differentiation, musical games, background music, responding emotionally to music, welcoming students with music, writing words to simple well-known melody, songs, background music to shape focus, calm down, energize and relax, record of a burst of applause.

8. Activities catering for naturalist intelligence: Creating observation notebooks of, describing changes in the local or global environment, caring for pets, wildlife, gardens, parks, using binoculars, telescopes, microscopes or magnifiers, drawing or taking pictures of natural objects, outdoor activities, natural and environmental materials and concepts, noticing relationships, making collocations, changing words in brackets into correct forms, classifying and categorizing activities, background music in the form of sounds created in the natural world.

\section{RESEARCH METHOD}

The method employed in this research was quasi experimental design. It involved two groups, namely the experimental group and the control group. The experimental group received treatment by MI-Based English Classroom Activities, while the control group received treatment by traditional way of teaching. This is supported by Gay, et al (2006) state that control group is needed for comparison purpose to prove if the new treatment is more effective than other.

The population of this research was the eleventhgrade students of SMAN 2 Mamuju of West Sulawesi Province in Academic Year 2014/2015. The total numbers of the major of classes were two, namely class XI of IPA and XI of IPS. Both of classes consisted of 7 classes. The class of IPA consisted of 3 classes and the class of IPS consisted of 4 classes. Each class consisted of 31 students so the populations were 217 students.. The sample of this research was selected throughpurposive sampling technique. The researcher took two classes which have nearly the same of their English achievement and they were XI IPA 1 and XI IPA 2 . These two classes were then taken randomly to represent them as control and experimental group. XI IPA $A_{1}$ was chosen as the control group which consisted of 31 students, while XI IPA ${ }_{2}$ was chosen as experimental group which consisted of 31 students too. And the sample of this research was 62 students.

The instruments used to collect the data consisted of three kinds of instrument, namely; the inventory of MI, English test and questionnaire for interest. In the procedure of collecting data, the researcher collected the data by administering of inventory of MI, pre-test, post-test, and questionnaire. 
The researcher gave the treatment to the students of experimental group and control group. The data were collected from the three instruments that were analyzed by using the following procedures:

1. The Inventory of MI consisted of ninety (90) statements that referred to MI response. The test used Guttman Scale by using two options. Each number noted certain measurement namely: (1) yes and (0) no. The score 0 response showed the statement did not relate to the participant's state and the score 1 response showed the statement related to the participant's state.This instrument was intended to measure the students' MIprofiles as a consideration to apply MI-Based English Classroom Activities.

2. Tabulating the score of the students' English test from both the control and experimental groups.

3. Calculating the mean score and standard deviation of the students' English of both groups test by using SPSS 21 .

4. Testing the hypothesis of the significant differences between the students' who are taught MI-Based English Classroom Activitiesfor experimental group andthe students' who are taught by using traditional way for control group by calculating the value of t-test.

5. Calculating the value of test for the significant differences between control and experimental groups in their gain scores.

6. Analyzing the data from the questionnaire to see the students' interest toward the implementation of MI-Based English Classroom Activities based on Likert Scale.

\section{RESULT AND DISCUSSIONS}

\section{The Students' MI Profiles}




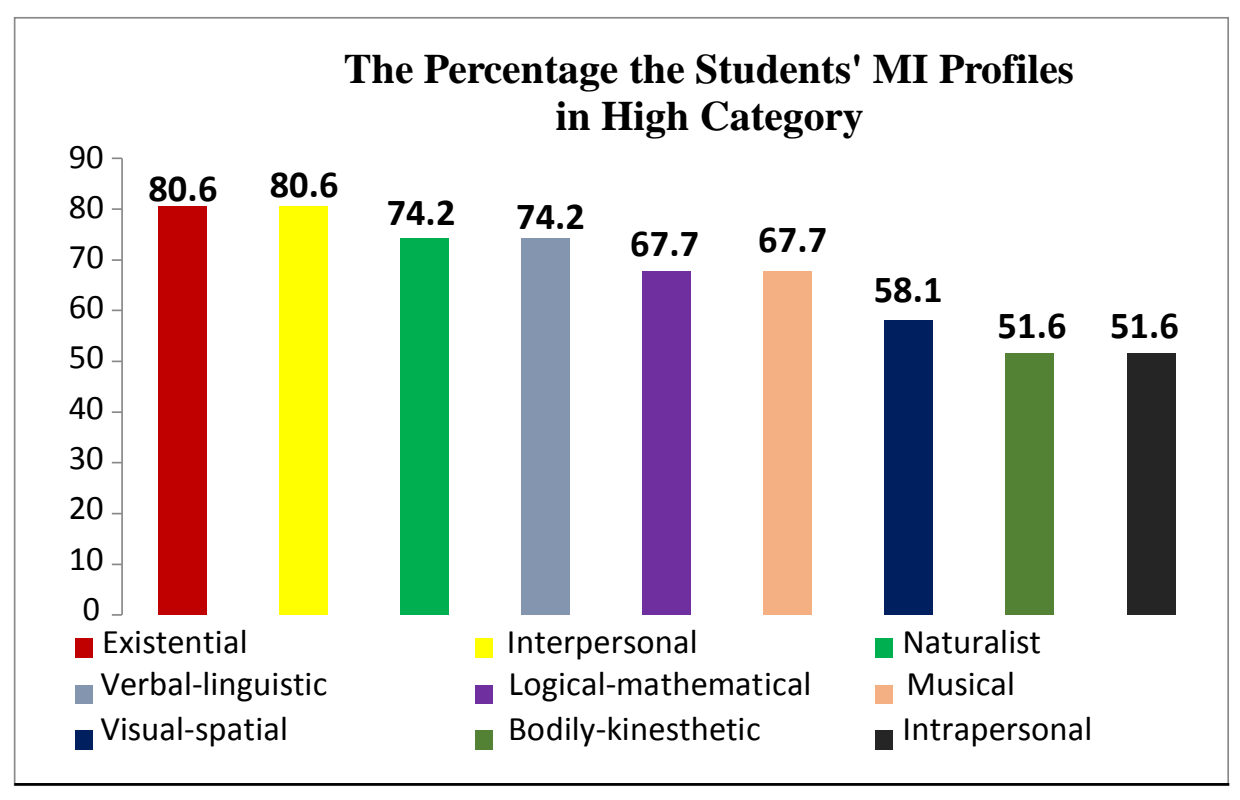

Figure 1 the Percentage of Students' MI Profiles in High Category

The data above only explains that the students' MI profiles in high category showed that 1) $80.6 \%$ students in existential and interpersonal intelligences, 2) $74.2 \%$ students in verbal-linguistic and naturalist intelligences, 3) $67.7 \%$ students in logical-mathematical and musical intelligences, 4) $58.1 \%$ students in visual-spatial intelligence, 5) $51.6 \%$ students in bodilykinesthetic and intrapersonal intelligences. The data describes that the students' MI profiles that the first level are existential and interpersonal intelligences, the second level are verbal-linguistic and naturalist intelligences, the third level are logical-mathematical and musical intelligences, the forth level are visual-spatial intelligence, the fifth level are bodily-kinesthetic and intrapersonal intelligences.

\section{Increasing of Students' Learning English before and after Treatment}

a. The Classification of the Students' English Test Score in Pre-test and Post-test 
Table 1

The Frequency and Percentage of the Students' English test inPre-test

\begin{tabular}{|c|l|c|c|c|c|c|}
\hline \multirow{2}{*}{ No } & \multirow{2}{*}{$\begin{array}{c}\text { Range of } \\
\text { Score }\end{array}$} & \multicolumn{2}{c|}{$\begin{array}{c}\text { Control } \\
\text { Group }\end{array}$} & \multicolumn{2}{c|}{$\begin{array}{c}\text { Experimental } \\
\text { Group }\end{array}$} \\
\cline { 4 - 7 } & & F & \% & F & \% \\
\hline 1 & Excellent & $96-100$ & 0 & 0.0 & 0 & 0.0 \\
\hline 2 & Very good & $86-95$ & 0 & 0.0 & 0 & 0.0 \\
\hline 3 & Good & $76-85$ & 2 & 6.5 & 1 & 3.2 \\
\hline 4 & Fairly good & $66-75$ & 6 & 19.4 & 4 & 12.9 \\
\hline 5 & Fair & $56-65$ & 7 & 22.6 & 14 & 45.2 \\
\hline 6 & Poor & $36-55$ & 16 & 51.6 & 12 & 38.7 \\
\hline 7 & Very poor & $00-35$ & 0 & 0.0 & 0 & 0.0 \\
\hline \multicolumn{2}{r|r}{ Total } & $\mathbf{3 1}$ & $\mathbf{1 0 0 . 0}$ & $\mathbf{3 1}$ & $\mathbf{1 0 0 . 0}$ \\
\hline
\end{tabular}

The data on the table above shows that the students' English test in both control and experimental group explained different frequency and percentage of seventh categories. In the control group: no one student in very poor category, $16(51.6 \%)$ students in poor category, $7(22.6 \%)$ students in fair category, $6(19.4 \%)$ students in fairly category, $2(6.5 \%)$ students in good category and no one student in very good and excellent categories. While in the experimental group: no one student in very poor category, 12 $(38.7 \%)$ students in poor category, $14(45.2 \%)$ students in fairly category, 4 $(12.9 \%)$ students in fairly category, $1(3.2 \%)$ student in good category and no one student in very good and excellent categories.

Table 2

The Frequency and Percentage of the Students' English test in Post-test

\begin{tabular}{|c|l|c|c|c|c|c|}
\hline \multirow{2}{*}{ No } & \multirow{2}{*}{ Classification } & \multirow{2}{*}{$\begin{array}{c}\text { Range of } \\
\text { Score }\end{array}$} & \multicolumn{2}{|c|}{$\begin{array}{c}\text { Control } \\
\text { Group }\end{array}$} & \multicolumn{2}{c|}{$\begin{array}{c}\text { Experimental } \\
\text { Group }\end{array}$} \\
\cline { 4 - 7 } & & & $\mathbf{F}$ & $\mathbf{\%}$ & $\mathbf{F}$ & \% \\
\hline 1 & Excellent & $96-100$ & 0 & 0.0 & 7 & 22.6 \\
\hline 2 & Very good & $86-95$ & 15 & 48.4 & 8 & 25.8 \\
\hline 3 & Good & $76-85$ & 2 & 6.5 & 12 & 38.7 \\
\hline 4 & Fairly good & $66-75$ & 5 & 16.1 & 4 & 12.9 \\
\hline 5 & Fair & $56-65$ & 3 & 9.7 & 0 & 0.0 \\
\hline 6 & Poor & $36-55$ & 6 & 19.4 & 0 & 0.0 \\
\hline 7 & Very poor & $00-35$ & 0 & 0.0 & 0 & 0.0 \\
\hline \multicolumn{2}{r}{ Total } & & $\mathbf{3 1}$ & $\mathbf{1 0 0 . 0}$ & $\mathbf{3 1}$ & $\mathbf{1 0 0 . 0}$ \\
\hline
\end{tabular}


The data on the table above that the students' achievement increased in posttest. In the control group: no one student in very poor category, $6(19.4 \%)$ students in poor category, 3 (9.7 \%) students in fair category, $5(16.1 \%)$ students in fairly good category, $2(6.5 \%)$ students in good category and 15 $(48.4 \%)$ students in very good and no one student in excellent category. While at experimental group, no one student in very poor, poor, and fair categories, $4(12.9 \%)$ students in fairly good, $12(38.7 \%)$ students in good category, 8 (25.8 5) students in very good and the last 7 (22.6\%) students in excellent.

The score distribution for control group and experimental group in post-test showed the difference from the pre-test. After conducting the treatment to both of the groups, it showed that more improve in experimental group by the implementation of MI-Based English Classroom Activities than the conventional teaching in control group. It means that the MI-Based English Classroom Activities were effective to increase students' English achievement.

b. The Mean Score and Standard Deviation of Students' English Achievement

Table 3

The Mean Score and Standard Deviation of the Students' English Test in Pre-test and Post-test

\begin{tabular}{|l|c|c|c|c|}
\hline \multirow{2}{*}{} & \multicolumn{2}{|c|}{ Control Group } & \multicolumn{2}{c|}{ Experimental Group } \\
\cline { 3 - 6 } & Pre-test & Post-test & Pre-test & Post-test \\
\cline { 2 - 5 } N Valid & 31 & 31 & 3 & 31 \\
Mean score & 0 & 0 & 1 & 0 \\
Missing & 61.77 & 73.06 & 0 & 85.32 \\
Std. Deviation & 11.29 & 12.50 & 59.8 & 10.40 \\
\hline
\end{tabular}

The data on the table above that there were difference of students' mean score and standard deviation of students' English test. The data analysis showedthat the students' mean score of control group were greater in posttest (73.06) than pre-test (61.77) or $73.06>61.77$. And control group hada range from post-test (73.06) to pre-test (61.77) was 11.29. While the students' mean score of experimental group was greater in post-test (85.32) after conducting treatment than pre-test $(59.84)$ or $85.32>59.84$. 
And experimental group as a range from post-test (85.32) to pre-test (59.84) was 25.48. The comparison of range means score between control and experimental group was 11.29 and 25.48. It means that the range increase of experimental group was more twofold than control group.

This case proved the implementation of MI-Based English Classroom Activities in experimental group significantly increased or using MI-Based English Classroom Activities was effective to increase students' English achievement in Learning English.

Furthermore the standard deviation of control group explained that pre-test (11.29) and post-test (12.50). It means that in control group had differences of students' variety score in English test. While the standard deviation of experimental showed pre-test (10.53) and post-test (10.40). It means that in experimental group after conducting treatment did not have differences of students' variety score in English test because it had nearly same standard deviation score. Although, it occurred significantly increase score in English test and it can be seen the comparison pre-test (59.84) and post-test (85.32) that had range 25.48.

Table 4

The Probability Value of t-test of the Students' English Achievement in Pre-test and Post-test

\begin{tabular}{|c|c|c|c|c|c|}
\hline & t-table & t-count & $\begin{array}{c}2 \text { Tailed Value } \\
\text { (Probability } \\
\text { Value) } \\
\end{array}$ & (a) & Remarks \\
\hline $\begin{array}{l}\text { Pre-test in } \\
\text { Experimental } \\
\text { and Control } \\
\text { Groups }\end{array}$ & \multirow{2}{*}{2.000} & 0.698 & 0.488 & \multirow{2}{*}{0.05} & $\begin{array}{l}\text { There was no different } \\
\text { or Null Hypothesis was } \\
\text { accepted }\end{array}$ \\
\hline $\begin{array}{l}\text { Post-test in } \\
\text { Experimental } \\
\text { and Control } \\
\text { Groups }\end{array}$ & & 4.198 & 0.001 & & $\begin{array}{lr}\text { Significantly } & \text { Different } \\
\text { or } & \text { Alternative } \\
\text { Hypothesis } & \text { was } \\
\text { accepted } & \end{array}$ \\
\hline
\end{tabular}


The data on the table above that the Probability value (0.488) was higher than the level of significance at $(\alpha)=(0.05)$ and the degree of freedom 62 . The data also showed that the t-count value was smaller than t-table $(0.698<$ 2.000). It indicated thatthe Alternative Hypothesis $\left(\mathrm{H}_{1}\right)$ was rejected and the Null Hypothesis $\left(\mathrm{H}_{0}\right)$ was accepted. After treatment, the researcher found that the Probability Value (0.00) was smaller than the level of significance at $(\alpha)=(0.05)$ and the degree of freedom 62. The data also showed that the $t-$ count value was higher than t-table $(4.198>2.000)$. It indicated thatthe Alternative Hypothesis $\left(\mathrm{H}_{1}\right)$ was accepted and the Null Hypothesis $\left(\mathrm{H}_{0}\right)$ was rejected. It means that the implementation of MI-Based English Classroom Activities could increase the students' English Achievement.

\section{Table 5}

The Probability Value of t-test of the Difference between Control And Experimental Group in their Gain Scores

\begin{tabular}{|c|c|c|c|c|c|}
\hline Group & Mean & $\begin{array}{c}\text { Standard } \\
\text { Deviation }\end{array}$ & -count & $\begin{array}{c}\text { Calculated } \\
\text { t-Value }\end{array}$ & $\begin{array}{c}\text { Remarks } \\
\text { at }(\boldsymbol{\alpha})=\mathbf{0 . 0 5}\end{array}$ \\
\hline $\begin{array}{c}\text { Control Group } \\
(\mathrm{N}=31)\end{array}$ & 11.29 & 9.217 & 5.725 & 0.00 & Significant \\
\hline $\begin{array}{c}\text { Experimental } \\
\text { Group (N=31) }\end{array}$ & 25.48 & 10.276 & & & \\
\hline
\end{tabular}

The data on the table above that $\mathrm{t}$-value or probability $(0.00)$ was smaller than the level of significance $(\alpha)=(0.00<0.05)$ and $t$-count was higher than t-table $(5.725>2.000)$. It means that there was significant difference of students' achievement between who were taught MI-Based English Classroom Activities for experimental group and the students who were taught by using conventional way, or in the other word Alternative Hypothesis $\left(\mathrm{H}_{1}\right)$ was accepted. It means that the implementation of MIBased English Classroom Activities was able to give greater contribution in teaching and learning English or the implementation of MI-Based English Classroom Activities was more effective than others. 


\section{Students' Interest}

Table 6

Percentage of the Students' Interest toward the Implementation of MI-Based English Classroom Activities

\begin{tabular}{|c|c|c|c|c|}
\hline \multirow[t]{2}{*}{ No } & \multirow[t]{2}{*}{ Classification } & \multirow[t]{2}{*}{$\begin{array}{c}\text { Range } \\
\text { of Score }\end{array}$} & \multicolumn{2}{|c|}{$\begin{array}{c}\text { Interest Toward MI-Based } \\
\text { English Classroom } \\
\text { Activities } \\
\end{array}$} \\
\hline & & & $\mathbf{F}$ & $\%$ \\
\hline 1 & $\begin{array}{l}\text { Strongly } \\
\text { Interested }\end{array}$ & $85-100$ & 18 & 58.1 \\
\hline 2 & Interested & $69-84$ & 13 & 41.9 \\
\hline 3 & Moderate & $52-68$ & 0 & 0.0 \\
\hline 4 & Uninterested & $36-51$ & 0 & 0.0 \\
\hline 5 & $\begin{array}{l}\text { Strongly } \\
\text { Uninterested }\end{array}$ & $20-35$ & 0 & 0.0 \\
\hline & \multicolumn{2}{|c|}{ Total } & 31 & 100.0 \\
\hline
\end{tabular}

The data of the students' on the table above indicates that the implementation of MI-Based English Classroom Activities showed that: there were $18(58.1 \%)$ students in strongly interested classification, 13 (41.9\%) students in interested classification, and no one student in moderate, uninterested and strongly interested classifications. Based on the data can be concluded that $58.1 \%$ students in experimental group were strongly interested to implementation of MI-Based English Classroom Activities. It means this strategy was reasonable to be applied in teaching and learning English.

Table 7

The Mean Score and Standard Deviation of Students' Interest

\begin{tabular}{|c|c|c|c|}
\hline \multirow{3}{*}{$\mathrm{N}$} & \multirow[b]{2}{*}{ Valid } & Strongly interested & Interested \\
\hline & & 18 & 13 \\
\hline & Missing & 0 & 5 \\
\hline Mean s & & 90.67 & 78.54 \\
\hline Std. De & & 4.47 & 2.70 \\
\hline
\end{tabular}


Further analysis showed that the mean score of students' interest toward the implementation of MI-Based English Classroom Activities in Learning English were 90.67 and 78.54 which were categorized as strongly interested and interested.

\section{CONCLUSION AND SUGGESTION}

The students' MI profiles showed that $80.6 \%$ students were in existential and interpersonal intelligences, $74.2 \%$ students in verbal-linguistic and naturalist intelligences, $67.7 \%$ students in logical-mathematical and musical intelligences, $58.1 \%$ students in visual-spatial intelligence, $51.6 \%$ students in bodily-kinesthetic and intrapersonal intelligences. To decide the students' MI profiles was very significant because it became as a consideration of implementation of MI-Based English Classroom Activities.

The implementation of MI-Based English Classroom Activities increased students' achievement. This strategy also was more effective than conventional way in teaching or learning English. This case was proved through tabulation data either pre-test and post-test in both groups namely control and experimental group. To know MI-Based English Classroom Activities was more effective, of course as a consequence in tabuation of data would test the hyphotheses whether they were accepted or not. The researcher found that the Probability value (0.488) was higher than the level of significance at $(\alpha)=(0.05)$. The $\mathrm{t}$-count value was smaller than $\mathrm{t}$-table $(-$ $0.698<2.000)$.It indicated that the Alternative Hypothesis $\left(\mathrm{H}_{1}\right)$ was rejected and the Null Hypothesis $\left(\mathrm{H}_{0}\right)$ was accepted. In the other word, there was no significant difference between the students English achievement in pre-test before treatment. After treatment, the researcher found that the Probability value $(0.00)$ was smallest than the level of significance at $(\alpha)=(0.05)$. The $t$ count value was higher than t-table $(4.198>2.000)$. It indicated that the Alternative Hypothesis $\left(\mathrm{H}_{1}\right)$ was accepted and the Null Hypothesis $\left(\mathrm{H}_{0}\right)$ was rejected. In the other word, there was significant difference between the students' English achievement in post-test after giving the treatment by using MI-Based English Classroom Activities. It means that the implementation of MI-Based English Classroom Activities could increase the students' English Achievement.

The students are interested toward implementation of MI-Based English Classroom Activities in learning English. It could be proved of the result of students' interest was obtained by analyzing frequency and percentage. Their results were $18(58.1 \%)$ students strongly interested, $13(41.9 \%)$ students were interested, and no one student was moderate, uninterested and strongly interested. It means that this strategy was reasonable to be applied in teaching and learning English. 
In briefly, the implementation of MI-Based English Classroom Activities was more effective than conventional way or teaching in learning English. MI-Based English Classroom Activities helps the students to improve their achievement in learning English. Moreover, this strategy provides opportunity to develop their multiple capabilities of learning. The MI-Based English Classroom Activities has developed the readiness of the students to acquire the knowledge of English. Also it motivated the students to understand the concepts easily, since this strategy gave pleasurable values in learning English. It also provides nine different potential pathways in learning and to develop the various skills in English.

\section{REFERENCES}

Berman, M. (1998). A Multiple Intelligences Road to an ELT Classroom.UK: Crown House Publishing Limited.

Brualdi, A. C. (1996). Multiple intelligences: Gardner's Theory. ERIC DigestAvailable:http://www.eric.ed.gov/contentdelivery/servlet/ ERICS ervlet?accno=ED410226.

Byrne, Donn. (1998). Teaching Writing Skills. Hongkong: Longman Group (FE) Ltd.

Campbell. L., Campbell, B., \& Dickinson, D. (1996). Teaching and Learning through Multiple Intelligences. Massachusetts: Allyn and Bacon.

Chapman, C. (1993). If the shoe fits...How to Develop Intelligences in the Classroom.Glenview: Pearson.

Chatib, M. (2011a). Sekolahnya Manusia. Mizan Media Utama (MMU).

Chatib. M. (2011b). Gurunya Manusia. Mizan Media Utama (MMU).

Chauhan.R.S.M. (2009). Effectiveness of Multiple Intelligence Based Teaching in Teaching English for Primary School Students. India.(http:/www.internationalresearchjournal.com and accessed on January 15, 2014) 
Christison, M. A. (1996). Teaching and Learning Languages through MI. TESOL Journal, 6 (1), 10-14.

Gardner, H. (1983). Frames of Mind: The Theory of Multiple Intelligences. New York: Basic Books.

Gardner, H. (1993). Multiple Intelligences: The theory in practice. New York: Basic Books.

Gardner, H. (1999). Intelligence reframed: Multiple intelligences for the 21st century. New York: Basic Books.

Gay. L. R., Mills. Geoffrey E., Airasian. Peter. (2006). Education Research: Competencies for Analysis and Application. The Eighth Edition.Florida: International University. Person Merrill Prentice Hall.

Hajhashemi. K. (2011). The Relationship between Iranian EFL High School Students' Multiple Intelligence Scores and their Use of Learning Strategies.Iran. (http://www.ccsenet.org/elt and accessed on January 15, 2014)

Ibnian. K.S.S. (2013). Implications of Multiple Intelligences Theory in ELT Field. The World Islamic Sciences and Education University (WISE) Language Center. Amman. Yordania.

Ibragimova. N. (2011). Multiple Intelligences Theory in Action in EFL Classes: A Case Study. Thesis: Eastern Mediterranean University,Turkey.(http:// www.internationalresearchjournal.com and accessed on January 15, 2014)

Soleimani. H, Moinnzadeh. A, Kassaian.Z and Ketabi S. (2012). The Effect of Instruction Based on Multiple Intelligences Theory onthe Attitude and Learning of General English. University of

Isfahan, Isfahan, Iran. (http:// www.internationalresearchjournal.com and accessed on January 15, 2014) 